\section{ANALISIS YURIDIS KEWENANGAN MAHKAMAH KONSTITUSI DALAM MELAKUKAN PENGUJIAN UNDANG-UNDANG TERHADAP UNDANG- UNDANG DASAR DI INDONESIA ${ }^{1}$} Oleh: Patrick Frend Wongkar ${ }^{2}$

Ronald J. Mawuntu ${ }^{3}$

Donna O. Setiabudhi ${ }^{4}$

\begin{abstract}
ABSTRAK
Penelitian ini dilakukan dengan tujuan untuk mengetahui bagaimana kedudukan Mahkamah Konstitusi dalam sistem ketatanegaraan Indonesia, sebagai lembaga peradilan (yudikatif) baru, yang berwenang menguji konstitusionalitas suatu undang-undang dan bagaimana prosedur pengujian undang-undang terhadap undang-undang dasar yang dilakukan oleh Mahkamah Konstitusi di Indonesia.
\end{abstract} Dengan menggunakan metode peneltian yuridis normatif, disimpulkan: 1. Kedudukan Mahkamah Konstitusi sebagai lembaga negara baru dalam sistem ketatanegaraan Indonesia pasca-amandemen UUD 1945, dan selanjutnya memiliki kewenangan untuk melakukan uji materiil suatu undang-undang terhadap undang-undang dasar, apakah terjadi pertentangan atau tidak, adalah merupakan indikasi suatu negara demokrasi. Kehadiran Mahkamah Konstitusi adalah jawaban bagi para pencari keadilan yang merasa hak konstitusionalnya dilanggar dengan berlakunya suatu undang-undang. 2. Hukum Acara Mahkamah Konstitusi adalah hukum formil yang berfungsi untuk menegakkan hukum materilnya, yaitu bagian dari hukum konstitusi yang menjadi wewenang Mahkamah Konstitusi. Berbeda dengan hukum acara lain hukum acara Mahkamah Konstitusi memiliki karakteristik khusus, karena hukum materil yang hendak ditegakkan tidak merujuk pada undang-undang atau kitab undang-undang tertentu, melainkan konstitusi sebagai hukum dasar sistem hukum itu sendiri. Prosedur pengujian undang-undang oleh Mahkamah Konstitusi adalah dilakukan mengenai formil dan materilnya. Formil adalah berkenaan dengan bagaimana undang-undang itu di buat, siapa yang membuatnya sedangkan

\footnotetext{
${ }^{1}$ Artikel Skripsi

2 Mahasiswa pada Fakultas Hukum Unsrat, NIM 14071101519

3 Fakultas Hukum Unsrat, Guru Besar Ilmu Hukum

${ }^{4}$ Fakultas Hukum Unsrat, Doktor Ilmu Hukum
}

materiil adalah isi daripada suatu undangundang yang dianggap bertentangan dengan konstitusi. Permohonan yang diajukan oleh pemohon harus didaftarkan melalui kepaniteraan Mahkamah Konstitusi untuk diperiksa kelengkapan administrasinya, selanjutnya dilakukan proses pendahuluan, pemeriksaan pokok perkara hingga putusan. Dan putusan Mahkamah Konstitusi tersebut adalah jenis putusan yang berkarakter final dan mengikat.

Kata kunci: Analisis Yuridis, Kewenangan, Mahkamah Konstitusi, Pengujian UndangUndang, Undang-Undang Dasar Di Indonesia

\section{PENDAHULUAN}

\section{A. Latar Belakang}

Putusan Mahkamah Konstitusi terhadap pengujian konstitusionalitas suatu undangundang bersifat final, artinya dalam hal pelaksanaan kewenangan ini tidak ada mekanisme banding atau kasasi terhadap putusan yang dibuat Mahkamah Konstitusi untuk perkara-perkara yang berkenaan dengan kewenangannya dalam menguji undang-undang terhadap undang-undang dasar.

Undang-undang dalam kenyataannya seringkali merugikan hak konstitusional warga negara. Padahal seharusnya undang-undang itu adalah produk hukum yang bisa menjamin hak setiap warga negara sesuai amanat konstitusi. Sudah bukan rahasia lagi jika ada undangundang yang merupakan hasil dari kesepakatan (deal-dealan) demi keuntungan pribadi (profit) elit-elit politik dan kepentingannya.

Lembaga Setara Institute mencatat ada 62 undang-undang yang diajukan uji materi ke Mahkamah Konstitusi sepanjang Agustus 2016 - Agustus 2017. ${ }^{5}$ Undang-undang yang paling banyak digugat adalah Undang-undang Nomor 8 Tahun 2015 Tentang pemilihan Gubernur, Bupati dan Walikota. Terhadap undang-undang tersebut telah 17 kali dimohonkan pengujian ke Mahkamah Konstitusi. Satu undang-undang saja sudah demikian banyaknya permohonan pengujian yang dilakukan ke Mahkamah Konstitusi, bisa dibayangkan jika berapa banyak permohonan pengujian yang dimohonkan untuk undang-undang yang lain yang dianggap merugikan hak konstitusional warga negara.

${ }^{5}$ www.Nasional.Kompas.comdiakses pada hari Rabu 20 Juni 2018 jam 19:33 WITA 
Sebagai suatu lembaga negara baru pascaamandemenkonstitusi, Mahkamah Konstitusi berwenang menguji konstitusionalitas suatu undang-undang.

Berdasarkan uraian latar belakang diatas, maka penulis tertarik untuk mengangkat judul "Analisis Yuridis kewenangan Mahkamah Konstitusi Dalam melakukan Pengujian Undang-Undang Terhadap Undang-Undang Dasar di Indonesia" guna dibahas lebih lanjut dalam penulisan skripsi ini.

\section{B. Rumusan Masalah}

1. Bagaimana kedudukan Mahkamah Konstitusi dalam sistem ketatanegaraan Indonesia, sebagai lembaga peradilan (yudikatif) baru, yang berwenang menguji konstitusionalitas suatu undangundang?

2. Bagaimana prosedur pengujian undangundang terhadap undang-undang dasar yang dilakukan oleh Mahkamah Konstitusi di Indonesia?

\section{Metode Penelitian}

Penelitian yang akan digunakan dalam penulisan hukum ini adalah penelitian Yuridis normatif yaitu penelitian yang dilakukan dengan cara meneliti bahan pustaka atau data sekunder yang terdiri dari bahan hukum primer, bahan hukum sekunder, dan bahan hukum tersier dari masing-masing hukum normatif. Bahan-bahan tersebut disusun secara sistematis, dikaji, kemudian dibandingkan dan ditarik suatu kesimpulan dalam hubungannya dengan masalah yang diteliti.

\section{HASIL DAN PEMBAHASAN}

A. Kedudukan Mahkamah Konstitusi Dalam Sistem Ketatanegaraan Indonesia Sebagai Lembaga Peradilan Yang Berwenang Menguji Konstitusionalitas Undang-Undang Keberadaan Mahkamah Konstitusi sebagai lembaga negara yang menangani perkaraperkara ketatanegaraan tertentu yang diatur menurut ketentuan Pasal $24 \mathrm{C}$ perubahan ketiga UUD 1945, berarti sistem kekuasaan yang terdapat dalam ketatanegaraan Republik Indonesia mengalami perubahan. Mahkamah Konstitusi memiliki peranan yang strategis terhadap perimbangan kekuasaan (checks and balances) antarlembaga negara dalam sistem ketatanegaraan Republik Indonesia, yaitu sebagai penjaga atau pengawal konstitusi.

Kedudukan Mahkamah Konstitusi di bidang yudikatif (peradilan) adalah sebagai lembaga negara yang berdiri sendiri, terpisah dari Mahkamah Agung. Hal itu ditegaskan melalui pengaturan Undang-undang Nomor 24 Tahun 2003 tentang Mahkamah Konstitusi yang menentukan bahwa, Mahkamah Konstitusi merupakan salah satu lembaga negara yang melakukan kekuasaan kehakiman yang merdeka untuk menyelenggarakan peradilan, dan bertanggung jawab untuk mengatur organisasi, personalia, administrasi, dan keuangannya sendiri, serta dapat mengatur lebih lanjut hal-hal yang diperlukan bagi kelancaran pelaksanaan tugas-tugas serta wewenangnya.

Berdasarkan otoritas yang diberikan UUD 1945 pada Mahkamah Konstitusi berarti, kedudukan Mahkamah Konstitusi sebagai pelaku kekuasaan kehakiman dalam sistem kekuasaan di Negara Republik Indonesia dimaksudkan sebagai lembaga yang mandiri untuk menyelenggarakan peradilan terhadap perkara-perkara ketatanegaraan tertentu yang diatur melalui Pasal 7 A juncto Pasal 7 B juncto pasal 24C Perubahan Ketiga UUD 1945.

Karena produk hukum merupakan refleksi dari konfigurasi politik yang melahirkannya, maka ada kemungkinan bahwa setiap produk hukum itu lebih sarat dengan muatan politik yang mungkin bertentangan dengan hukum yang lebih tinggi yang menjadi dasarnya. Dengan kata lain, ada kemungkinan bahwa undang-undang sebagai produk politik memuat isi yang tidak sesuai dengan UUD. Untuk itu, hak menguji secara materiil terhadap Undangundang segera dilembagakan. ${ }^{6}$

Undang-undang merupakan landasan hukum yang menjadi dasar pelaksanaan dari seluruh kebijakan dari seluruh kebijakan yang akan dibuat oleh pemerintah. Legal policy yang dituangkan dalam undang-undang menjadi sebuah sarana rekayasa sosial, yang memuat kebijaksanaan yang hendak dicapai pemerintah, untuk mengarahkan masyarakat menerima nilai-nilai baru.

\footnotetext{
6 Moh. Mahfud MD, Membangun Politik Hukum Menegakkan Konstitusi, Raja Grafindo Persada, Jakarta, 2011, hal 79
} 
Melalui judicial review, setiap produk hukum dapat dinilai konsistensinya dengan UUD dan jika tidak konsisten, undang-undang tersebut dapat dinyatakan batal. Di Indonesia, pada era Orde Baru sudah ada peraturan tentang judicial review, tetapi ia terbatas pada peraturan perundang-undangan yang mengatur judicial review terhadap peraturan perundangundangan yang derajatnya dibawah undangundang.

Mahfud MD seorang mantan Ketua Mahkamah Konstitusi dalam penelitiannya mengemukakan fakta bahwa hampir setiap undang-undang (tertulis yang berkarakter konservatif) memberikan "space" yang luas kepada pemerintah untuk membuat interpretasi dengan berbagai peraturan pelaksanaan melalui delegasi perundangundangan maupun droit function, yakni menentukan secara sepihak materi peraturan yang bernuansaenunsiatif. ${ }^{7}$ Kenyataan ini dapat juga member peluang kepada pemerintah untuk membuat peraturan pelaksanaan atas undang-undang menurut visi dan kekuatan politiknya sendiri.

Lebih lanjut menurut Mahfud MD, jika berbicara tentang judicial review di dalam politik hukum tidak dapat dilepaskan dari pembicaraan tentang hukum perundangundangan atau peraturan perundangundangan. Sebab, judicial review itu bekerja atas dasar peraturan perundang-undangan yang tersusun hierarkis. Pengujian oleh lembaga yudisial dalam judicial review adalah untuk menilai sesuai atau tidaknya satu perundang-undangan dengan peraturan perundang-undangan yang lebih tinggi secara hierarkis. Judicial review tidak bisa dioperasionalkan tanpa ada peraturan perundang-undangan yang tersusun secara hierarkis. ${ }^{8}$

\section{B. Prosedur Pengujian Undang-Undang Terhadap Undang-Undang Dasar Oleh Mahkamah Konstitusi di Indonesia}

Sebagai sebuah badan peradilan, Mahkamah Konstitusi memiliki hukum acara, yang lazim disebut dengan hukum acara Mahkamah Konstitusi. Hukum acara Mahkamah
Konstitusi adalah "hukum formil yang berfungsi untuk menegakkan hukum materilnya, yaitu bagian dari hukum konstitusi yang menjadi wewenang Mahkamah Konstitusi. Berbeda dengan hukum acara lain (misalnya: hukum acara pidana, hukum acara perdata dan hukum acara peradilan tata usaha negara), "hukum acara Mahkamah Konstitusi memiliki karakteristik khusus, karena hukum materil yang hendak ditegakkan tidak merujuk pada undang-undang atau kitab undang-undang tertentu, melainkan konstitusi sebagai hukum dasar sistem hukum itu sendiri. Dilihat dari jenis kewenangannya, hukum acara sengketa kewenangan lembaga negara, hukum acara pembubaran partai politik, dan hukum acara memutus pendapat Dewan Perwakilan Rakyat mengenai dugaan pelanggaran hukum Presiden dan/atau Wakil Presiden.

Mahkamah Konstitusi memiliki asas-asas praktik peradilan sebagaimana diatur dalam hukum acara yang terdaoat di dalam Undangundang tentang Mahkamah Konstitusi, Undangundang tentang Kekuasaan Kehakiman, dan asas-asas yang telah diakui berlaku universal. Menurut Maruarar Siahaan, Hakim Konstitusi periode pertama, ada sejumlah asas yang berlaku dalam hukum acara di Mahkamah Konstitusi, yaitu :

1. Asas persidangan terbuka untuk umum;

2. Asas hakim yang independen dan imparsial;

3. Asas peradilan dilaksanakan scara cepat, sederhana dan murah;

4. Asas hak semua pihak untuk didengar secara seimbang (Audi et AlteramPartem);

5. Asas hakim aktif dan juga pasif dlam proses persidangan;

6. Asas hakim mengetahui hukumnya (lus Curia Novit). ${ }^{9}$

Hukum acara mengenai peradilan konstitusi diatur dalam undang-undang Nomor 24 Tahun 2003 tentang Mahkamah Konstitusi. Menurut Maruarar Siahaan, pengaturan tentang hukum acara di dalam Undang-Undang tentang Mahkamah Konstitusi tersebut sangat sumir, sehingga masih menyisahkan begitu banyak kekosongan. Itulah sebabnya pembuat undang- 
undang tentang Mahkamah Konstitusi menyerahkan kepada Mahkamah Konstitusi untuk mengatur lebih lanjut tentang hukum acara di Mahkamah Konstitusi.

Undang-undang tentang Mahkamah Konstitusi menyatakan bahwa: "Mahkamah Konstitusi dapat mengatur lebih lanjut hal-hal yang diperlukan bagi kelancaran tugas dan wewenangnya menurut undang-undang ini". ${ }^{10}$ Atas dasar ini, Mahkamah Konstitusi telah melakukan penyempurnaan hukum acara di Mahkamah Konstitusi melalui beberapa Peraturan Mahkamah Konstitusi.

Dalam praktiknya, hukum acara di Mahkamah Konstitusi mengadopsi dan mengadaptasi secara mutatis mutandis (dengan perubahan-perubahan seperlunya) dari hukum acara yang ada di lingkungan peradilan lain, misalnya peradilan pidana, perdata, dan tata usaha Megara, dan juga hukum acara dari Negara lain yang relevan. Atas dasar mutatis mutandis ini, hukum acara Mahkamah Konstitusi dalam praktiknya mengacu pada hukum acara lain yang tidak diatur dalam Undang-Undang tentang Mahkamah Konstitusi, tetapi sifat perkaranya selaras dengan perkara di Mahkamah Konstitusi. Untuk perkara impeachment, hukum acara pidana juga mutatis mutandis berlaku. Dalam perkara pengujian undang-undang, hukum acara perdata juga mutatis mutandis berlaku. Untuk perkara sengketa kewenangan antarlembaga Negara, hukum acara Peradilan Tata Usaha Negara juga mutatis mutandisiberlaku. Karena hukum acara Mahkamah Konstitusi kurang lengkap, "hukum acara Mahkamah Konstitusi tumbuh secara perlahan (evolving) dalam praktek sehingga terkadang terlihat seolah-olah konsisten". ${ }^{11}$

Khusus berkenaan mengenai pengujian konstitusionalitas undang-undang, Mahkamah Konstitusi telah memiliki hukum acara pengujian undang-undang terhadap UndangUndang Dasar 1945, baik yang diatur dalam Undang-undang Nomor 24 Tahun 2003 tentang mahkamah Konstitusi maupun dalam Peraturan Mahkamah Konstitusi Nomor 06/PMK/2005 tentang Pedoman Beracara dalam Perkara Pengujian Undang-undang.

\footnotetext{
10 Pasal 86 Undang-Undang Nomor 24 Tahun 2003 Tentang Mahkamah Konstitusi

${ }^{11}$ /bid hal 48
}

Dalam hukum acara pengujian undangundang di Mahkamah Konstitusi, semua perkara konstitusi yang masuk ke Mahkamah Konstitusi disebut sebagai perkara permohonan, bukan perkara gugatan. Ini karena "hakikat perkara konstitusi di Mahkamah Konstitusi tidaklah bersifat adversarial atau contentious yang berkenaan dengan pihak-pihak yang saling bertabrakan kepentingan satu sama lain seperti dalam perkara perdata ataupun tata usaha Negara. ${ }^{12}$ Undang-undang yang diperkarakan di peradilan Mahkamah Konstitusi adalah undang-undang yang menyangkut kepentingan umum semua warga Negara, bukan hanya menyangkut kepentingan pihak atau individu yang memperkarakan undang-undang tersebut.

Putusan yang dijatuhkan oleh majelis Hakim Konstitusi terhadap suatu undang-undang akan membawa akibat hukum tidak hanya bagi pihak atau individu yang mengajukan perkara tersebut ke Mahkamah Konstitusi, tetapi juga orang lain, lembaga Negara dan aparatur pemerintah serta masyarakat umumnya. Inilah mengapa perkara pengujian undang-undang di Mahkamah Konstitusi tidak dalam bentuk gugatan, melainkan permohonan. Selain itu, subjek hukum yang mengajukan perkara pengujian undang-undang disebut sebagai pemohon, bukan penggugat.

Untuk dapat mengajukan permohonan pengujian undang-undang ke Mahkamah Konstitusi, para pencari keadilan (justiciabellen) harus memiliki kedudukan hukum (legal standing) yang sah agar permohonan dapat diproses oleh majelis hakim Konstitusi. Menurut Harjono, "legal standing" adalah keadaan di mana seseorang atau suatu pihak ditentukan memenuhi syarat dan karena itu mempunyai hak untuk mengajukan permohonan penyelesaian perselisihan atau sengketa atau perkara di depan Mahkamah Konstitusi. Dengan demikian, pemohon harus mampu membuktikan keabsahan legal standing-nya sehingga permohonannya dapat diperiksa, diadili dan diputus oleh Mahkamah Konstitusi. Persyaratan legal standing mencakup syarat formil dan syarat materil. ${ }^{13}$

Syarat formil untuk legal standing menyatakan

bahwa:

13/bid hal 49 
Pemohon adalah pihak yang menganggap hak dan/atau kewenangan konstitusionalitasnya dirugikan oleh berlakunya undang-undang yaitu:

a. Perorangan warga Negara Indonesia;

b. Kesatuan masyarakat hukum adat sepanjang masih hidup dan sesuai dengan prkembangan masyarakat dan prinsip Negara Kesatuan Republik Indonesia yang diatur dalam undangundang;

c. Badan hukum publik atau privat ; atau

d. Lembaga Negara. ${ }^{14}$

Sementara syarat materil legal standing dirumuskan secara ketat oleh Mahkamah Konstitusi melalui putusannya sebagai berikut:

a. Adanya hak konstitusional pemohon yang diberikan oleh undang-undang Dasar 1945;

b. Bahwa hak konstitusional pemohon tersebut dianggap oleh pemohon tekah dirugikan suatu undang-undang yang diuji;

c. Bahwa kerugian yang dimaksud bersifat spesifik (khusus) dan aktual atau setidaknya bersifat potensial yang menurut penalaran yang wajar dapat dipastikan akan terjadi;

d. Adanya hubungan sebab akibat (causal verband) antara kerugian dan berlakunya undang-undang yang dimohonkan untuk diuji;

e. Adanya kemungkinan bahwa dengan dikabulkannya permohonan maka kerugian konsitusional yang didalilkan tidak akan atau tidak lagi terjadi. ${ }^{15}$

Adanya pemohon atau permohonan sangat esensial bagi pelaksanaan kewenangan Mahkamah Konstitusi, termasuk kewenangan menguji konstitusionalitas undang-undang atas konstitusi. Tanpa adanya permohonan pengujian undang-undang dari seseorang atau badan hukum, maka Mahkamah Konstitusi sama saja dengan tidak memiliki kewenangan.

Setiap permohonan yang diajukan ke Mahkamah Konstitusi harus diperiksa terlebih dahulu oleh Panitera Mahkamah Konstitusi

\footnotetext{
14 Pasal 51 Undang-Undang Nomor 24 Tahun 2003

Tentang Mahkamah Konstitusi

15 Putusan Perkara Pengujian Undang-Undang Nomor: 006/PUU-II/2005 dan Nomor: 010/PUU-III/2005
}

untuk memeriksa kelengkapan administrasi permohonan sehingga dapat diketahui apakah permohonan sudah lengkap atau belum. Kelengkapan permohonan adalah berkas permohonan yang telah memenuhi ketentuan seperti ditulis dengan bahasa Indonesia, ditandatangani oleh pemohon atau kuasanya, berkas permohonan berjumlah 12 (dua belas) rangkap, memuat dengan jelas nama dan alamat pemohon, dan disertai dengan alat-alat bukti yang mendukung permohonan. ${ }^{16}$

Permohonan yang lengkap kemudian akan dicatat dalam buku Registrasi Perkara Konstitusi (BRPK) dan selanjutnya dalam waktu 14 (empat belas) hari Mahkamah Konstitusi harus menetapkan hari sidang pertamanya. Proses pemeriksaan persidangan di Mahkamah Konstitusi terdiri dari pemeriksaan pendahuluan dalam persidangan pertama dan pemeriksaan pokok perkara setelah selesai pemeriksaan pendahuluan.

Setelah seluruh proses pemeriksaan persidangan dilakukan, hakim konstitusi kemudian akan menjatuhkan putusan terhadap perkara permohonan pengujian undangundang yang dibahas dalam rapat permusyawaratan hakim. Putusan Mahkamah Konstitusi yang mengabulkan permohonan harus didasarkan pada sekurang-kurangnya dua alat bukti. ${ }^{17}$

Putusan Mahkamah Konstitusi yang telah diucapkan atau dibacakan tidak berlaku surut (retroaktif), tetapi berlaku ke depan (progresif) sejak setelah selesai diucapkan. Artinya, keadaan hukum yang baru telah mulai berlaku sejak saat putusan Mahkamah Konstitusi selesai diucapkan atau dibacakan di dalam sidang pleno yang terbuka untuk umum. Pemerintah, lembaga negara lain, dan masyarakat umum yang terkait dengan putusan itu wajib menghormati dan melaksanakan putusan tersebut. Putusan Mahkamah Konstitusi juga berkarakter final dan mengikat.

Pelaksanaan putusan final oleh Mahkamah Konstitusi sangat bergantung pada kesediaan otoritas publik di luar Mahkamah Konstitusi untuk melaksanakan putusan final tersebut. Mahkamah Konstitusi sama sekali tidak dapat

\footnotetext{
16 Pasal 32 Undang-Undang Nomor 24 Tahun 2003 Tentang Mahkamah Konstitusi

17 Pasal 45 ayat (2) Undang-Undang Nomor 24 Tahun 2003 Tentang Mahkamah Konstitusi
} 
memastikan pelaksanaan putusan-putusannya. Akibatnya putusan final Mahkamah Konstitusi terhadap pengujian undang-undang terhadap undang-undang dasar berpotensi menjadi tidak implementatif di lapangan setelah putusan itu dibacakan oleh hakim konstitusi. ${ }^{18}$

Pada prinsipnya setiap putusan Mahkamah Konstitusi haruslah dilaksanakan dengan sebagaimana mestinya. Artinya harus ditindak lanjut oleh semua warga negara dan pemerintah. Karena putusan hakim konstitusi adalah merupakan salah satu bentuk cara melindungi hak-hak setiap warga negara yang dijamin oleh konstitusi. Sebagaimana yang dikatakan oleh Daniel Lev yang berbunyi " Constitutionalism is meaningless without resources of power, in some form, both to achieve and sustain it". ${ }^{19}$ Artinya, konstitusionalisme itu tidak ada artinya tanpa adanya sumber kekuatan, dalam sesuatu bentuk, untuk mencapai dan mempertahankannya.

Untuk menjamin konsistensi dan relevansi sebuah undang-undang dengan konstitusi dan dalam rangka check and balance, pelembagaan hak uji materiil terhadap undang-undang ini diperlukan dan tidak ada halangan konstitusionalnya. ${ }^{20}$ Karena sejatinya konstitusi adalah hukum tertinggi yang merupakan jaminan hukum bagi setiap warga negara dan tidak ada suatu peraturan dibawah konstitusi yang bisa merugikan hak konstitusional warga negara. Apabila ada, maka jalannya adalah melakukan uji materiil undang-undang yang dianggap merugikan tersebut ke Mahkamah Konstitusi Republik Indonesia.

Semua konstitusi yang pernah dan sedang berlaku di negara Republik Indonesia secara resmi mencantumkan demokrasi sebagai salah satu asas kenegaraannya. ${ }^{21}$ Untuk itu, maka wajib bagi negara (melalui Mahkamah Konstitusi) untuk bias mengakomodir kepentingan konstitusional rakyat apabila ada undang-undang yang merugikan konstitusionalitasnya.

\footnotetext{
${ }^{18}$ Manan, Op.Cit, hal 56

19 Adnan Buyung Nasution, Pikiran dan Gagasan Demokrasi Konstitusional, Kompas, Jakarta, 2010, hal 145

${ }^{20}$ Moh. Mahfud MD, Politik Hukum di Indonesia, Raja Grafindo Persada, Jakarta, 2012, hal 351

${ }^{21}$ lbid hal 361
}

\section{PENUTUP}

\section{A. Kesimpulan}

1. Pembentukan Mahkamah Konstitusi sebagai pengadilan konstitusi berdiri atas dasar asumsi adanya supremasi konstitusi konstitusi yang menjadi hukum tertinggi yang mendasari atau melandasi kegiatan negara serta sebagai parameter untuk mencegah negara bertindak secara tidak konstitusional. Dengan demikian, gagasan pembentukan Mahkamah Konstitusi merupakan upaya yang ditujukan untuk penyelenggaraan kekuasaan dan ketatanegaraan yang benar sesuai hukum dasar atau konstitusi. Kedudukan Mahkamah Konstitusi sebagai lembaga negara baru dalam sistem ketatanegaraan Indonesia pasca-amandemen UUD 1945, dan selanjutnya memiliki kewenangan untuk melakukan uji materiil suatu undangundang terhadap undang-undang dasar, apakah terjadi pertentangan atau tidak, adalah merupakan indikasi suatu negara demokrasi. Kehadiran Mahkamah Konstitusi adalah jawaban bagi para pencari keadilan yang merasa hak konstitusionalnya dilanggar dengan berlakunya suatu undang-undang.

2. Sebagai sebuah badan peradilan, sebagaimana badan peradilan lainnya Mahkamah Konstitusi memiliki hukum acara, yang lazim disebut dengan hukum acara Mahkamah Konstitusi. Hukum Acara Mahkamah Konstitusi adalah hukum formil yang berfungsi untuk menegakkan hukum materilnya, yaitu bagian dari hukum konstitusi yang menjadi wewenang Mahkamah Konstitusi. Berbeda dengan hukum acara lain hukum acara Mahkamah Konstitusi memiliki karakteristik khusus, karena hukum materil yang hendak ditegakkan tidak merujuk pada undang-undang atau kitab undang-undang tertentu, melainkan konstitusi sebagai hukum dasar sistem hukum itu sendiri. Prosedur pengujian undang-undang oleh Mahkamah Konstitusi adalah dilakukan mengenai formil dan materilnya. Formil adalah berkenaan dengan bagaimana undang-undang itu di buat, siapa yang 
membuatnya sedangkan materiil adalah isi daripada suatu undang-undang yang dianggap bertentangan dengan konstitusi. Permohonan yang diajukan oleh pemohon harus didaftarkan melalui kepaniteraan Mahkamah Konstitusi untuk diperiksa kelengkapan administrasinya, selanjutnya dilakukan proses pendahuluan, pemeriksaan pokok perkara hingga putusan. Dan putusan Mahkamah Konstitusi tersebut adalah jenis putusan yang berkarakter final dan mengikat.

\section{B. Saran}

Sebaiknya untuk kedepan terhadap putusan Mahkamah Konstitusi (terlebih khusus) mengenai putusan pengujian undang-undang, agar dibuat suatu ketentuan atau aturan khusus yang tegas terkait pemberian sanksi bagi pihakpihak yang tidak menjalankan atau menuruti isi putusan Mahkamah Konstitusi tersebut. Karena dalam kenyataannya banyak pihak yang tidak secara sukarela menjalankan amar putusan Mahkamah Konstitusi tersebut, padahal karakter putusannya adalah final dan mengikat (inkracht). Artinya tidak dapat lagi diajukan upaya hukum terhadapnya.

\section{DAFTAR PUSTAKA}

Anggono,BayuDwi.2014, Perkembangan Pembentukan Undang-Undang di Indonesia, Konstitusi Press, Jakarta.

Asshiddiqie, Jimly. 2012,Hukum Tata Negara dan Pilar-Pilar Demokrasi, Sinar Grafika, Jakarta.

. 2011,Perihal Undang-Undang, Raja Grafindo Persada, Jakarta. dan Safa'at, M. Ali. 2012,Teori Hans kelsen Tentang Hukum, Konstitusi Press, Jakarta.

Daulay, IkhsanRosyadaParluhutan. 2006, Mahkamah Konstitusi Memahami Keberadaannya Dalam Sistem Ketatanegaraan Republik Indonesia, Rineka Cipta, Jakarta.

Dicey, A.V. 2014,Pengantar Studi Hukum Konstitusi (Introduction to The Study of The Law of The Constitution), Nusamedia, Bandung.

Fatmawati. 2005, Hak Menguji (Toetsingrecht) Yang Dimiliki Hakim Dalam Sistem
Hukum Indonesia, Raja Grafindo Persada, Jakarta.

Fuady,Munir. 2010,Konsep Negara Demokrasi, RefikaAditama, Bandung. 2009,Teori Negara Hukum Modern (Rechstaat), RefikaAditama, Bandung.

Ibrahim, Jhonny. 2006,Teori dan Metodologi Penelitian Hukum Normatif, BayumediaPublishng. Malang.

Lubis,Solly. 2007,IImu Negara, Mandar Maju, Bandung.

.2009, IImu Pengetahuan PerundangUndangan, Mandar Maju, Bandung.

Mahfud MD, Moh. 2003,Demokrasi dan Konstitusi di Indonesia Studi Tentang Interaksi Politik dan Kehidupan Ketatanegaraan, Rineka Cipta, Jakarta.

Moh. 2011,Membangun Politik Hukum Menegakkan Konstitusi, Raja Grafindo Persada, Jakarta.

. 2012,Konstitusi dan Hukum Dalam

Kontroversi Isu, Raja Grafindo Persada, Jakarta.

. 2010,Perdebatan Hukum Tata Negara Pascaamandemen Konstitusi, Sinar Grafika, Jakarta.

.2012, Politik Hukum di Indonesia, Raja Grafindo Persada, Jakarta.

Manan,Munafrizal. 2012,Penemuan Hukum Oleh Mahkamah Kontitusi, Mandar Maju, Bandung.

Nasution, Adnan Buyung. 2010, Pikiran dan Gagasan Demokrasi Konstitusional, Kompas, Jakarta.

Soebechi, H. Imam. 2012,Judicial Review Perda Pajak dan Retribusi Daerah, Sinar Grafika, Jakarta.

Soemantri M, HRT. Sri. 2014,Hukum Tata Negara Indonesia Pemikiran dan Pandangan, Remaja Rosdakarya, Bandung.

Soekanto, Soerjono. 2006,Pengantar Penelitian Hukum. UI-Press. Jakarta.

Sunggono, Bambang.2011, Metode Penelitian Hukum, Raja Grafindo Persada, Jakarta.

Sudding,Sarifuddin. 2014, Perselingkuhan Hukum dan Politik Dalam Negara Demokrasi, Rangkang Education, Yogyakarta.

Syahuri,Taufiqurrohman. 2005, Hukum Konstitusi Proses dan Prosedur 
Perubahan UUD di Indonesia 19452002, Ghalia Indonesia, Bogor. . 2011,Tafsir Konstitusi Berbagai Aspek Hukum, Prenada Media Grup, Jakarta.

Tutik, Titik Triwulan. 2008,Pokok-Pokok Hukum Tata Negara Indonesia Pascaamandemen UUD 1945, Cerdas Pustaka, Jakarta.

Yuliandri. 2011,Asas-Asas Pembentukan Peraturan Perundang-Undangan Yang Baik (Gagasan Pembentukan UndangUndang Berkelanjutan), Raja Grafindo Persada, Jakarta.

Zuchron, Daniel. 2015,Menggugat Manusia Dalam Konstitusi;Kajian Filsafat Atas UUD 1945 Pasca-Amandemen, RayyanaKomunikasindo, Jakarta.

\author{
SUMBER-SUMBER LAIN \\ Undang-Undang Dasar Negara Republik \\ Indonesia Tahun 1945 \\ Undang-Undang Nomor 24 Tahun 2003 \\ Tentang Mahkamah Konstitusi \\ Undang-Undang Nomor 8 Tahun 2011 Tentang \\ Perubahan Undang-Undang Nomor 24 Tahun \\ 2003 Tentang Mahkamah Konstitusi \\ Putusan Perkara Pengujian Undang-Undang \\ Nomor: 006/PUU-II/2005 \\ Putusan Perkara Pengujian Undang-Undang \\ Nomor: 010/PUU-III/2005 \\ Peraturan Mahkamah Konstitusi Nomor \\ 06/PMK/2005 Tentang Pedoman \\ Beracara dalam Perkara Pengujian \\ Undang-undang. \\ www.Nasional.Kompas.com
}

